\title{
Erratum to: Procedure for Calculation of Potency and Efficacy for Ligands Acting on $\mathbf{G}_{\mathbf{s}^{-}}$and $\mathbf{G}_{\mathbf{i}^{-}}$-Coupled Receptors
}

\author{
Eddi Meier $\cdot$ Arne Schousboe $\cdot$ Bo Belhage
}

Published online: 26 October 2012

(c) Springer Science+Business Media New York 2012

\section{Erratum to: Neurochem Res}

\section{DOI 10.1007/s11064-012-0870-6}

In the original publication of the article, there are some errors found and the corrected version of the text is displayed below:

1. The phrase "or room temperature" in the fourth line of figure 2 caption needs to be omitted.

2. Under the Calculation Algorithms subsection, the second formula in the brackets below the fraction line should be read as $(\log$ EC50 - $\log \mathrm{s})$
The online version of the original article can be found under doi:10.1007/s11064-012-0870-6.

E. Meier $(\bowtie)$

NordicScienceAdvice I/S, Bringebakken 88, 3500 Værløse, Denmark

e-mail: eddimeier@mail.dk

\section{A. Schousboe}

Department of Drug Design and Pharmacology, Faculty

of Health and Medical Sciences, University of Copenhagen,

2100 Copenhagen, Denmark

B. Belhage

Institute of Surgery and Internal Medicine, Clinical Institutes, Bispebjerg Hospital, University of Copenhagen,

2400 Copenhagen, Denmark
3. Under discussion section, the lines $12-16$ of the third paragraph should read as " $\mathrm{G}_{\mathrm{i}}$ potencies based on $\mathrm{E}_{\text {err } 1}$ effect data on average became 3.4 (in some cases up 41) times less potent and when based on $E_{\text {err2 }}$ effect data became 2.2 (in some cases up to 12) times less potent than when based on $E_{\text {true }}$ effect data." 